\title{
EFFICACY OF ORGANIC AMENDMENTS AND SOIL SOLARIZATION AGAINST WILT SEVERITY AND THEIR EFFECTS ON PATHOGENIC FUNGI AND TOMATO PRODUCTION
}

\author{
aHayfa Jabnoun-Khiareddine*, a,bBoutheina Mejdoub-Trabelsi, aRania Aydi Ben Abdallah, \\ 'Riad S. R. El-Mohamedy, aMejda Daami-Remadi \\ a UR13AGR09-Integrated Horticultural Production in the Tunisian Centre-East, Regional Research Centre on Horticulture \\ and Organic Agriculture, University of Sousse, 4042, Chott-Mariem, Sousse, Tunisia. \\ $\mathbf{b}$ Higher School of Agriculture of Kef, University of Jendouba, Tunisia. \\ c Plant Pathology Department, National Research Center, Dokki, Giza, Egypt.
}

\section{ART I C L E I N F O}

\section{Article history}

Received: March 21, 2020

Revised: June 24, 2020

Accepted: August 26, 2020

\section{Keywords}

Isolation frequency

Soilborne pathogens

Soil treatments

Solanum lycopersicum

Vascular disease

Yield
A B S T R A C T

Soil solarization coupled or not with three soil amendments (cattle manure, biocompost, and Biocat-15) was evaluated for its efficacy against vascular wilt severity on tomato plants grown under greenhouse conditions in a naturally infested soil. In solarized plots, wilt severity, estimated through the vascular discolouration extent and noted on randomly selected tomato plants, was significantly reduced following all the tested organic amendments. Complete wilt suppression was achieved using cattle manure. Vascular wilt severity reported on symptomatic tomato plants was $28 \%$ higher in non-solarized plots than in solarized ones, and this for all organic amendments combined. Plots amended with Biocat-15 showed 29\% less disease severity as compared to the two other treatments. Fungal isolations performed on Potato Dextrose Agar medium from roots, collars and stems of symptomatic and randomly selected plants, revealed the involvement of Fusarium oxysporum, F. solani, Rhizoctonia solani, Colletotrichum coccodes and $R$. bataticola in the observed wilts. Their isolation frequencies varied depending on wilt severity, solarization treatments (solarized or non-solarized) and tested soil amendments. Tomato production varied significantly depending on solarization treatments and tested organic amendments. Plants amended with cattle manure yielded significantly comparable production in the solarized and non-solarized plots. In contrast, this production parameter was reduced by 19 and 27\% following Biocompost and Biocat-15 treatments, respectively, on tomato plants grown in non-solarized plots. As for solarization effects, for all organic amendments combined, tomato production was significantly reduced by about $15 \%$ in the non-solarized greenhouse compared to the solarized one. Results from the current study showed that, under natural Tunisian conditions, a single application of solarization combined with organic amendment not only reduced wilt severity but also significantly enhanced tomato production. Thus, the repetitive combination of solarization and organic amendments could be a credible alternative for managing various soilborne fungal diseases and improving tomato yield in heavily infested fields.

Corresponding Author: Hayfa Jabnoun-Khiareddine

Email: jkhayfa@yahoo.fr

(C) The Author(s) 2020. 


\section{INTRODUCTION}

In Tunisia, soilborne fungal diseases are prevalent in almost all tomato (Solanum lycopersicum) growing areas. fusarium wilt, caused by Fusarium oxysporum f. sp. lycopersici (FOL), fusarium Crown and Root Rot, caused by $F$. oxysporum f. sp. radicis-lycopersici (FORL) and verticillium wilt, incited by Verticillium dahliae, are the most severe and devastating diseases (Hibar et al., 2005; Aydi Ben Abdallah et al., 2019; Jabnoun-Khiareddine et al., 2019; Nefzi et al., 2019). Their prevalence as single and/or multiple infections leads to considerable yield losses yearly.

In Tunisia, the management of these pathogens is a hard task due mainly to their long-lasting resting structures resides in the soil and to their ability to infect the plant vascular tissues and it's below ground organs. Furthermore, the absence of registered fungicides emphasized the need for effective and environmentally safe alternatives. Many approaches have been tested in Tunisia, under laboratory and tomato greenhouse conditions, where indigenous fungi and bacteria (Jabnoun-Khiareddine et al., 2009a, 2009b), fungal and bacterial endophytes (Aydi Ben Abdallah et al., 2019; Nefzi et al., 2019), aqueous and organic extracts (Kerkeni et al., 2007; Nefzi et al., 2017), resistant rootstocks (Hibar et al., 2006a; Jabnoun-Khiareddine et al., 2019), composts (Hibar et al., 2006b; Kerkeni et al., 2007), as well as some resistance inducers (ElMohamedy et al., 2014; Jabnoun-Khiareddine et al., 2015) have been explored. However, farmers are still facing the increasing pressure of soilborne pathogens which frequently reaches high inoculum densities in the soil, due to the continuous tomato cropping on the same field, the disease-conducive climate, the cultural practices used, and the emergence of new pathogen races (Hibar et al., 2007; Aydi Ben Abdallah et al., 2019; Jabnoun-Khiareddine et al., 2019).

In the presence of such inoculum pressure, the use of a single control measure is not sufficient to efficiently manage such diseases. Thus, it is crucial to markedly reduce soil infestation level below the critical threshold, in order to guarantee a favourable environment for tomato growth and production and also to enhance the proliferation of beneficial microorganisms (Blok et al., 2000). An integrated approach that uses all available control strategies could manage pathogen populations, like soil solarization, alone or in combination with other methods. In fact, among the non-chemical control methods explored, soil solarization is considered as an increasingly attractive soil disinfestation approach, especially for Mediterranean countries such as Tunisia. Solarization is a pre-planting soil treatment consisting of a hydrothermal process in which moist soil is covered with transparent plastic mulches and exposed to sunlight, allowing it to heat to temperatures that are lethal to many soilborne plant pathogens, insects, and weed seeds (Katan, 1981). The long-term efficacy of soil solarization against soilborne diseases and its ability to improve crop yield has been demonstrated on various vegetable crops grown under field or greenhouse conditions and for more than one season (Davis, 1991). Soil solarization controls soilborne pathogens either directly through physico-thermal killing, or indirectly via the stimulation of antagonistic activity (Katan and Devay, 1991) or by weakening the resting structures of pathogens released in the soil, thus exposing them to antagonistic microorganisms (Freeman and Katan, 1988). Moreover, one of the advantages of soil solarization is its compatibility with other physical, chemical, and biological methods for effective control of soilborne diseases (Gamliel et al., 2009). The effects of solarization against soilborne pathogens may be more enhanced by the addition of organic amendments (composts, animal manures and green manures) and/or biological control agents (Gamliel and Stapleton, 1993; Keinath, 1996). Increasing attention has been given to the use of such organic amendments to improve soil properties, plant health and yield and to control soilborne pathogens (Bonanomi et al., 2007). In fact, application of organic amendments and solarization, singly or in combination, can alter the chemical, physical, and biological properties of treated soils and consequently result in pathogen bio-suppression and subsequently, effective control of associated diseases (Klein et al., 2007).

As in Tunisia, the summer temperatures are relatively high, soil solarization could be a successful alternative for the control soilborne bio-aggressors. However, as in the Tunisian Sahel (centre-east regions), soils are heavily infested with soilborne pathogens, soil solarization applied alone maybe not consistently effective for their control. Thus, the objective of this study was to evaluate the effectiveness of various organic amendments (animal manure, biocompost and a 
humic corrector of vegetable origin), applied singly or following soil solarization, against wilt diseases and their subsequent effects on associated fungal pathogens and tomato production.

\section{MATERIALS AND METHODS Plant Material}

Tomato cv. Sahel, commonly used for fresh market production under plastic greenhouses in the Tunisian Sahel regions, was used in this study. It is known to be resistant to FOL races 1 and 2, FORL and $V$. dahliae race 1 (Syngenta, 2015).

Seedlings were grown in alveolus plates $(3 \times 3 \mathrm{~cm})$ filled with sterilized peat ${ }^{\circledR}$ (Floragard Vertriebs $\mathrm{GmbH}$ für gartenbau, Oldenburg) under greenhouse conditions (16 h photoperiod, $65-75 \%$ relative humidity and $22-29{ }^{\circ} \mathrm{C}$ air temperature). They were watered regularly until reaching the two-true-leaf growth stage.

\section{Site, Climate and Soil}

Plastic greenhouse trial was conducted at the experimental station of the Regional Research Centre on Horticulture and Organic Agriculture, located in Teboulba region (centre-east of Tunisia). Soil is of sandy clay texture. The experimental plots were located in a vegetable field with a long history of tomato soilborne fungal diseases such as verticillium and fusarium wilts, Black dot, and Rhizoctonia stem canker. This site was under the conventional farming system and had a history of intensive commercial vegetable production. The local climate is semiarid/Mediterranean, with mild winters and hot, rainless summers. The mean maximum summer temperatures were $28{ }^{\circ} \mathrm{C}$ (June), $32.5{ }^{\circ} \mathrm{C}$ (July), $32{ }^{\circ} \mathrm{C}$ (August) and $29.2{ }^{\circ} \mathrm{C}$ (September). Two separate and nearby plastic greenhouses (solarized and nonsolarized) of $8 \times 60 \mathrm{~m}$-size were used in this study.

\section{Soil Solarization}

One day prior to solarization, the soil was prepared using a moldboard plough followed by a disk harrow and was irrigated under reaching the field capacity to take advantage of the greater effectiveness of solarization in moist soils. Solarization technique with 60 days duration was applied during the hottest period of the year (from 20 July to 20 September). The soil was manually covered with transparent polyethylene film (135 $\mu$ m thickness) which was stretched close to the soil surface and then anchored. The edges of the plastic sheet were covered with soil to avoid wind disturbance. At the end of the solarization period, the sheets were carefully removed, avoiding as much as possible any disturbance to the soil. For both greenhouses, the covering was done after soil solarization.

\section{Organic Amendment Application}

Three soil amendments were tested in the current study, i.e. cattle manure (CM), biocompost (BC) and Biocat-15 (B-15). The last treatment is a humic corrector of vegetable origin. $\mathrm{CM}$ is the most commonly used amendment by tomato farmers in the study region. Just after solarization, the solarized and non-solarized control greenhouses were similarly divided lengthwise into three $8 \times 20 \mathrm{~m}$-plots. Each plot was supplied with one of the three tested organic amendments. CM and BC were uniformly applied and hand incorporated on the soil surface at the rates of 35 and $11.5 \mathrm{t} \mathrm{ha}^{-1}$, respectively. The biocat- 15 was applied twice at the rate of $100 \mathrm{l} \mathrm{ha}^{-1}$, two days prior to planting and 12 days after tomato planting.

Planting was carried out 70 days post soil amendments with $\mathrm{CM}$ and $\mathrm{BC}$. Two-true-leaf growth stage seedlings were set into a $15-\mathrm{cm}$ high, $75-\mathrm{cm}$ wide raised bed plasticulture system with $75-\mathrm{cm}$ row spacing and $40-\mathrm{cm}$ in-row spacing. There were four beds in the greenhouse with two rows per bed. Seedlings were arranged according to a completely randomized factorial design, and the individual treatments were arranged as follows: solarized and $\mathrm{CM}$-amended, solarized and $\mathrm{BC}$-amended, solarized and B-15 amended, non-solarized and CMamended, non-solarized and $\mathrm{BC}$-amended, non-solarized and B-15 amended. There were 8 rows in the plot, and each individual treatment was arranged into eight rows of 35 seedlings each. Cultural management was consistent with typical commercial production in the region. Black plastic mulch and drip irrigation were used, and stake-and-weave cultural management was used to train the plants vertically.

\section{Monitoring of Disease Severity and Tomato Production}

For the assessment of wilt severity, plants were sampled at two dates, at 165- and 180-days post-planting. For the first sampling, 11 randomly selected plants (consecutive plants with or without wilt symptoms), were uprooted per row and per each individual treatment, while for the 
second, 11 symptomatic plants showing typical wilt signs were sampled.

For each sampled plant, stems were longitudinally cut and visually examined for the presence of vascular discolouration and the measurement of its spreading extent upward from collar when present. For each individual treatment, stems, collars, and roots of all sampled plants were brought to the laboratory for fungal isolations. They were mixed, surface-sterilized in $0.5 \% \mathrm{NaOCl}$, rinsed in sterile water, cut into 3-5 mmfragments, and plated on Potato Dextrose Agar (PDA) medium, and incubated at $25^{\circ} \mathrm{C}$ for 4 days.

The isolation frequency of each recovered fungus was calculated as the percentage of root, collar or stem fragments showing typical growing colonies relative to the total number of fragments plated on PDA medium. Isolated fungi were identified using classical taxonomic procedures and growth characteristics on the media. Furthermore, each harvest was noted per individual treatment, and the total production was calculated at the end of the trial, i.e. 190 days post-planting.

\section{Statistical Analyses}

For all measured parameters, statistical analyses were performed following a completely randomized factorial design with two factors: solarization treatment (solarized and non-solarized greenhouse) and soil amendments (CM, BC, and B-15). In total, 280 replicate plants were used per individual treatment. Means were separated using Duncan's Multiple Range test (at $P \leq$
0.05). Statistical analyses were performed using SPSS software version 16 for windows.

\section{RESULTS}

Combined Effect of Soil Solarization and Organic Amendments on Vascular Wilt Severity

The suppressive effect of soil solarization coupled or not with the three tested organic amendments against vascular wilt severity was evaluated on randomly chosen tomato plants (symptomatic and asymptomatic) and on selected wilted plants. Sampling was carried out at the end of the growing season per soil treatment and per greenhouse (solarized and non-solarized).

\section{Disease Severity Noted on Randomly Sampled Plants} Disease severity estimated through the vascular discolouration extent varied significantly (at $P \leq 0.05$ ) depending on solarization treatment (solarized or nonsolarized), tested soil amendments, and their interactions. In a solarized greenhouse, tomato plants were grown on CM- and Biocat-15-amended soil did not show any vascular discolouration compared to those grown on BC-treated soil where the vascular discolouration extent reached $15 \mathrm{~cm}$ from the collar and upward (Figure 1). However, in the non-solarized greenhouse, the most severe wilt, noted on randomly selected tomato plants, was observed on CM-amended plants where the vascular discolouration extent reached $65 \mathrm{~cm}$ compared to 15 and $5 \mathrm{~cm}$ noted on those treated with $\mathrm{BC}$ and Biocat-15, respectively.

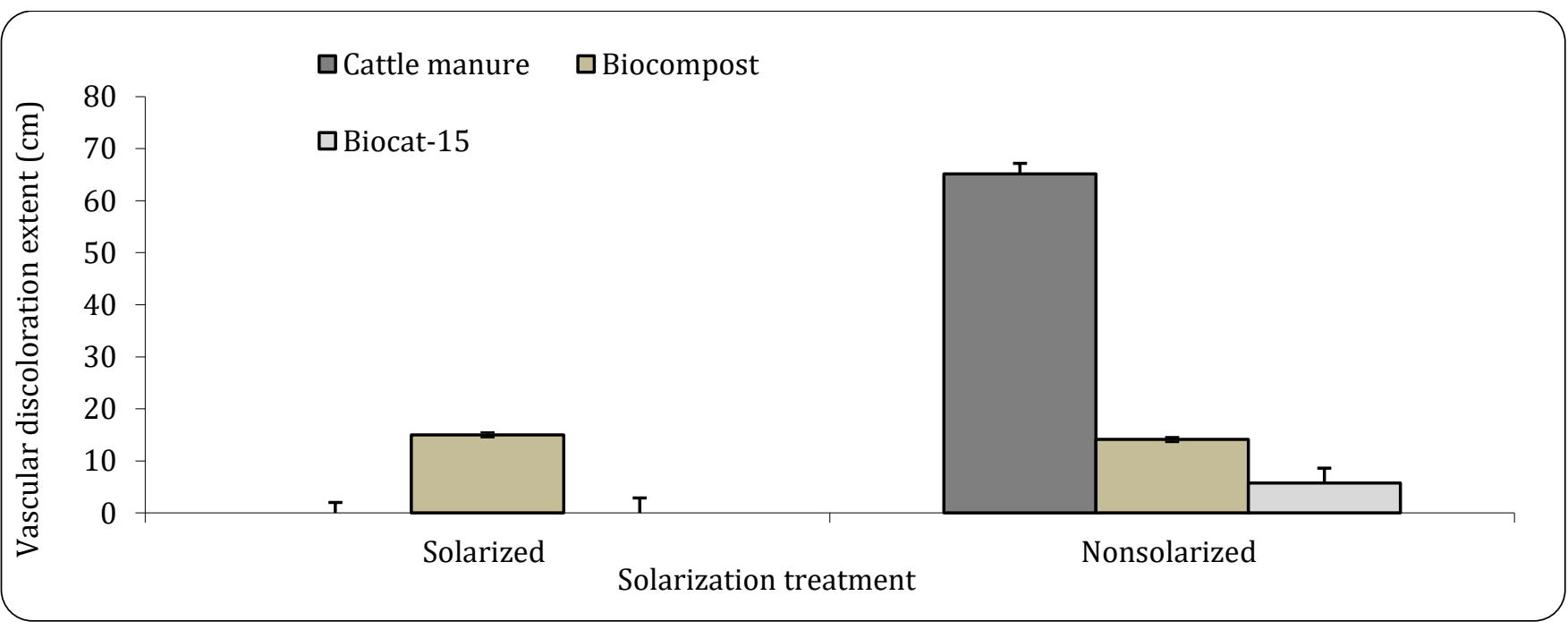

Figure 1: Vascular discolouration extent $(\mathrm{cm})$ noted on randomly collected tomato $\mathrm{cv}$. Sahel plants depending on solarization treatment (solarized or non-solarized) and tested organic amendments. For each individual treatment, data presented are means for 88 plants. 
LSD (Solarization treatments $\times$ Organic amendments) $=35.32 \mathrm{~cm}$ at $P \leq 0.05$.

Fungal isolations performed from roots, collars and stems of tomato plants randomly collected and representative of different treatments, revealed the presence of various soilborne fungi such as Fusarium oxysporum, F. solani, Rhizoctonia solani and Colletotrichum coccodes. As shown in Table 1, these soilborne fungi were isolated at different frequencies depending on the tested factors. F. oxysporum was isolated from 0 to $30 \%$ from all tomato organs and for all tested soil treatments tested, compared to $0-60 \%$ and $0-100 \%$, noted for $F$. solani and $R$. solani, respectively. C. coccodes was isolated from $30 \%$ of tomato roots collected from plants grown in nonsolarized and $\mathrm{BC}$-amended plots and from $10 \%$ of the roots of those grown on solarized and Biocat-15amended plots.

Table 1: Isolation frequency of phytopathogenic fungi from roots, collars and stems of randomly collected tomato plants depending on solarization treatment (solarized or non-solarized) and tested soil amendments.

\begin{tabular}{|c|c|c|c|c|c|}
\hline \multicolumn{6}{|c|}{ Roots } \\
\hline $\begin{array}{l}\text { Solarization } \\
\text { treatments }\end{array}$ & $\begin{array}{c}\text { Organic } \\
\text { amendments }\end{array}$ & $\begin{array}{l}\text { Fusarium } \\
\text { oxysporum }\end{array}$ & F. solani & $\begin{array}{l}\text { Rhizoctonia } \\
\text { solani }\end{array}$ & $\begin{array}{l}\text { Colletotrichum } \\
\text { coccodes }\end{array}$ \\
\hline \multirow{3}{*}{ Solarized } & Cattle manure & 30 & 0 & 60 & 0 \\
\hline & Biocompost & 30 & 0 & 40 & 0 \\
\hline & Biocat-15 & 0 & 10 & 100 & 0 \\
\hline \multirow{3}{*}{$\begin{array}{c}\text { Non- } \\
\text { solarized }\end{array}$} & Cattle manure & 0 & 0 & 100 & 0 \\
\hline & Biocompost & 0 & 20 & 70 & 30 \\
\hline & Biocat-15 & 0 & 20 & 100 & 0 \\
\hline \multicolumn{6}{|c|}{ Collars } \\
\hline \multirow{3}{*}{ Solarized } & Cattle manure & 20 & 10 & 40 & 0 \\
\hline & Biocompost & 0 & 20 & 0 & 0 \\
\hline & Biocat-15 & 0 & 0 & 10 & 10 \\
\hline \multirow{3}{*}{$\begin{array}{c}\text { Non- } \\
\text { solarized }\end{array}$} & Cattle manure & 10 & 60 & 0 & 0 \\
\hline & Biocompost & 0 & 30 & 0 & 0 \\
\hline & Biocat-15 & 0 & 0 & 20 & 0 \\
\hline \multicolumn{6}{|c|}{ Stems } \\
\hline \multirow{3}{*}{ Solarized } & Cattle manure & 20 & 20 & 30 & 0 \\
\hline & Biocompost & 10 & 10 & 30 & 0 \\
\hline & Biocat-15 & 10 & 10 & 0 & 0 \\
\hline \multirow{3}{*}{$\begin{array}{c}\text { Non- } \\
\text { solarized }\end{array}$} & Cattle manure & 0 & 50 & 0 & 0 \\
\hline & Biocompost & 20 & 0 & 0 & 0 \\
\hline & Biocat-15 & 10 & 0 & 0 & 0 \\
\hline
\end{tabular}

\section{Disease Severity on Symptomatic Plants}

Vascular wilt severity noted on symptomatic tomato plants varied significantly (at $P \leq 0.05$ ) depending on solarization treatment used and organic amendments tested, but no significant interaction was noted between the two factors. As shown in Figure 2, the vascular discolouration extent noted on plants collected from the non-solarized plots, whatever the organic amendment used, was $28 \%$ higher than that noted on symptomatic plants grown in solarized plots.

As for the single effects of the tested organic amendments (the cumulated data of solarized and nonsolarized treatments), Figure 3 shows that the severity of the vascular wilt noted on $\mathrm{CM}$-amended plants was significantly compared to that recorded on BC-treated plants, where the vascular discolouration extent reached almost $170 \mathrm{~cm}$ above the collar. Conversely, Biocat-15amended plants showed 29\% less disease severity compared to the two other amendments and the recorded vascular discolouration extent reached $125 \mathrm{~cm}$. Fungal isolations carried out on PDA medium from roots, collars and stems of wilted plants and representative of each individual treatment revealed the presence of Fusarium oxysporum, F. solani, Rhizoctonia solani, Colletotrichum coccodes, and $R$. bataticola and their involvement, with varying degrees, in the observed wilt symptoms (Table 2). In fact, whatever the organic amendment applied, F. oxysporum was isolated from tomato plants grown in the solarized greenhouse at 20$80,10-50$, and $20-40 \%$ from roots, collars, and stems, 
respectively.

However, in the non-solarized one, this fungus was recovered from sampled symptomatic tomato plants at 20-50, 30-60, and 60-90\% from roots, collars, and stems, respectively. The isolation frequency of $F$. solani varied from 0 to $10 \%$ in the solarized greenhouse and from 0 to
$30 \%$ in the non-solarized one. $R$. solani was the most frequently recovered fungus (isolation frequency varying from 10 to $100 \%$ ) from tomato plants whatever the solarization treatments and organic amendments tested. C. coccodes was isolated at $10 \%$ from roots of tomato plants grown in solarized and $\mathrm{CM}$-amended soils.

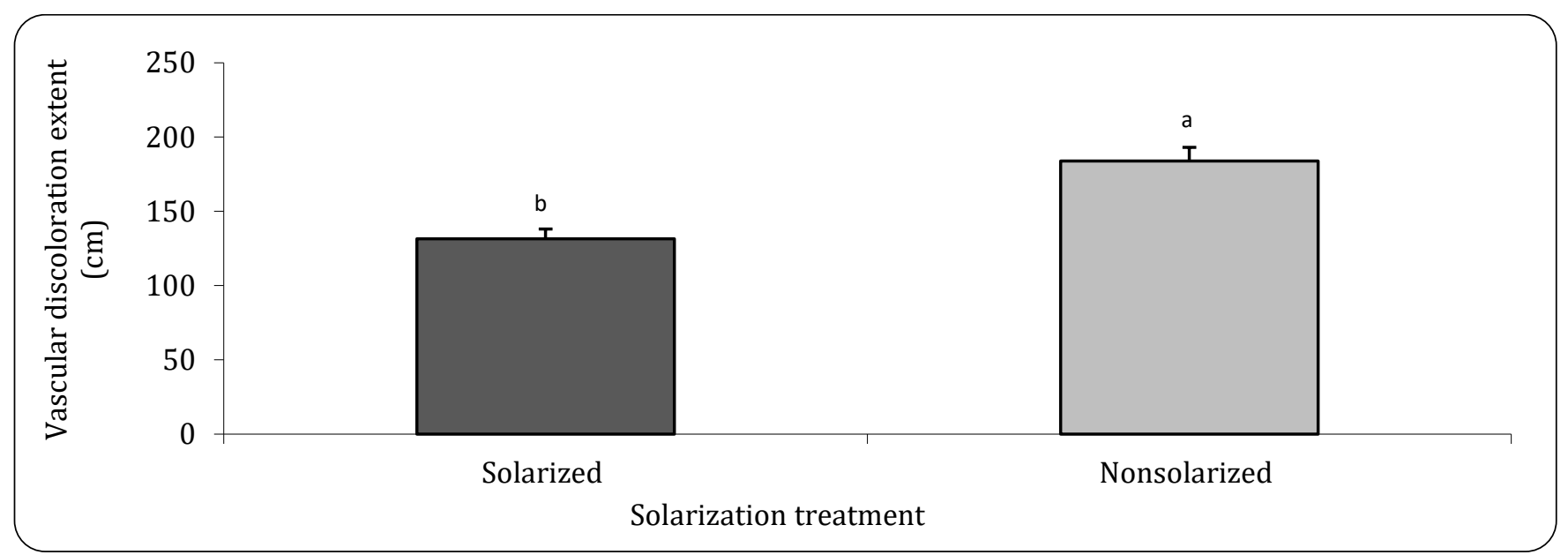

Figure 2: Vascular discolouration extent $(\mathrm{cm})$ noted on wilted tomato $\mathrm{cv}$. Sahel plants depending on solarization treatments (data for all organic amendments combined).

Bars sharing the same letter are not significantly different, according to Duncan's Multiple Range test $(P \leq 0.05)$. For each solarization treatment, data presented are means for 264 plants.

Table 2: Isolation frequency of phytopathogenic fungi from roots, collars, and stems of wilted tomato plants depending on solarization treatment (solarized or non-solarized) and tested soil amendments.

\begin{tabular}{|c|c|c|c|c|c|c|}
\hline \multicolumn{7}{|c|}{ Roots } \\
\hline $\begin{array}{l}\text { Solarization } \\
\text { treatments }\end{array}$ & $\begin{array}{c}\text { Organic } \\
\text { amendments }\end{array}$ & F. oxysporum & F. solani & R. solani & C. coccodes & R. bataticola \\
\hline \multirow{3}{*}{ Solarized } & Cattle manure & 30 & 10 & 10 & 10 & 0 \\
\hline & Biocompost & 80 & 0 & 10 & 0 & 0 \\
\hline & Biocat-15 & 20 & 0 & 100 & 0 & 0 \\
\hline \multirow{3}{*}{$\begin{array}{c}\text { Non- } \\
\text { solarized }\end{array}$} & Cattle manure & 50 & 0 & 100 & 0 & 0 \\
\hline & Biocompost & 30 & 10 & 100 & 0 & 0 \\
\hline & Biocat-15 & 20 & 0 & 100 & 0 & 0 \\
\hline \multicolumn{7}{|c|}{ Collars } \\
\hline \multirow{3}{*}{ Solarized } & Cattle manure & 10 & 0 & 100 & 0 & 0 \\
\hline & Biocompost & 20 & 0 & 100 & 0 & 0 \\
\hline & Biocat-15 & 50 & 10 & 90 & 0 & 0 \\
\hline \multirow{3}{*}{$\begin{array}{c}\text { Non- } \\
\text { solarized }\end{array}$} & Cattle manure & 60 & 0 & 100 & 0 & 10 \\
\hline & Biocompost & 30 & 0 & 60 & 0 & 20 \\
\hline & Biocat-15 & 60 & 0 & 100 & 0 & 0 \\
\hline \multicolumn{7}{|c|}{ Stems } \\
\hline \multirow{3}{*}{ Solarized } & Cattle manure & 20 & 0 & 100 & 0 & 0 \\
\hline & Biocompost & 20 & 10 & 60 & 0 & 80 \\
\hline & Biocat-15 & 40 & 0 & 100 & 0 & 0 \\
\hline \multirow{3}{*}{$\begin{array}{c}\text { Non- } \\
\text { solarized }\end{array}$} & Cattle manure & 90 & 30 & 10 & 0 & 0 \\
\hline & Biocompost & 60 & 10 & 20 & 0 & 0 \\
\hline & Biocat-15 & 70 & 20 & 30 & 0 & 0 \\
\hline
\end{tabular}




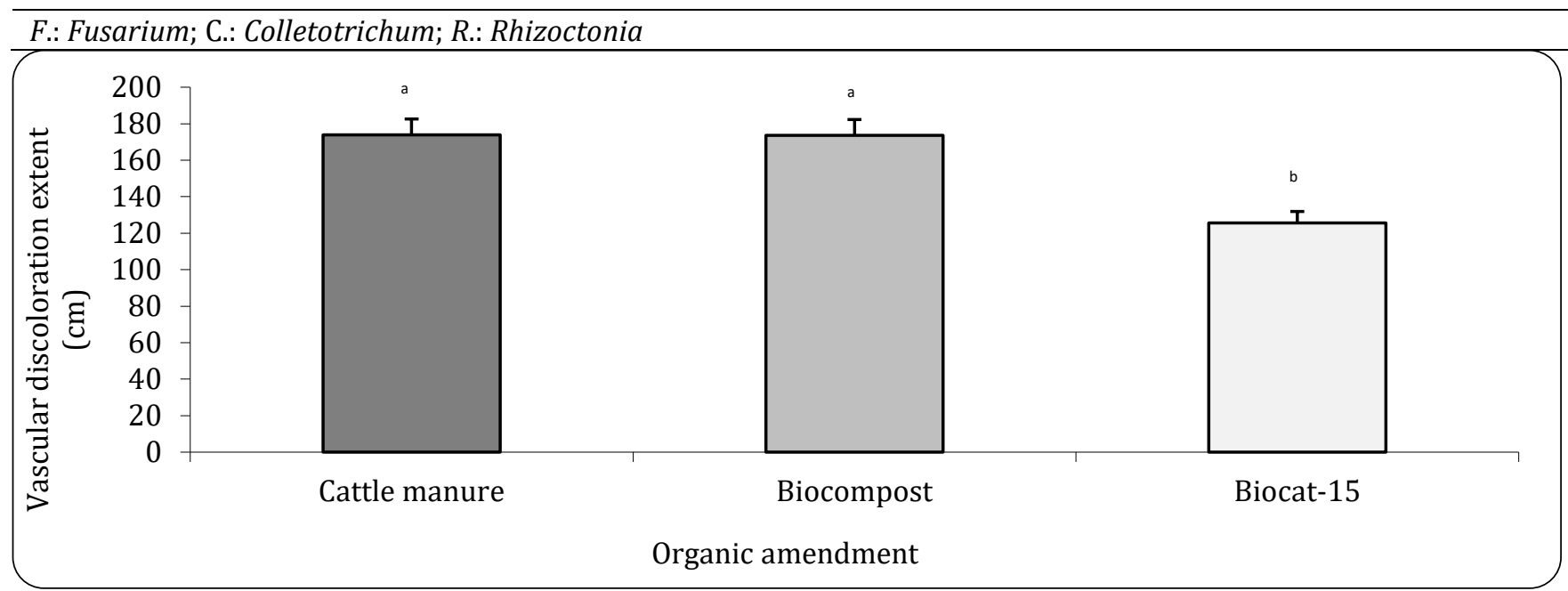

Figure 3: Vascular discolouration extent $(\mathrm{cm})$ noted on wilted tomato $\mathrm{cv}$. Sahel plants depending on tested organic amendments (data for all solarization treatments combined).

Bars sharing the same letter are not significantly different, according to Duncan's Multiple Range test $(P \leq 0.05)$. For each tested organic amendment, data presented are means for 176 plants.

As shown in Table 2, R. bataticola was isolated, at $80 \%$, only from stems of plants grown in solarized and BCamended plots. However, in the non-solarized greenhouse, this fungus was isolated, at 10 and $20 \%$, only from the collars of CM- and BC-amended plants, respectively.

\section{Combined Effect of Soil Solarization and Organic Amendment on Tomato Production}

The combined effect of soil solarization and tested organic amendments were evaluated through the cumulative production (i.e. a total of echeloned harvests) recorded till the end of the tomato growing season. ANOVA analysis indicated that tomato production varied significantly depending on solarization application and tested organic amendments. As shown in Figure 4, this production parameter varied significantly (at $P \leq 0.05$ ) depending on solarization treatments and amendments. The total production recorded on CM-amended plants was significantly comparable in solarized and nonsolarized plots while it was reduced by 19 and $27 \%$ in the non-solarized plots following $\mathrm{BC}$ supply and Biocat15 amendment, respectively.

Furthermore, as shown in Figure 5, and for combined data of all tested organic amendments, tomato production was significantly $15 \%$ higher in the solarized greenhouse $(\sim 687 \mathrm{~kg})$ as compared to the non-solarized one $(\sim 581 \mathrm{~kg})$.

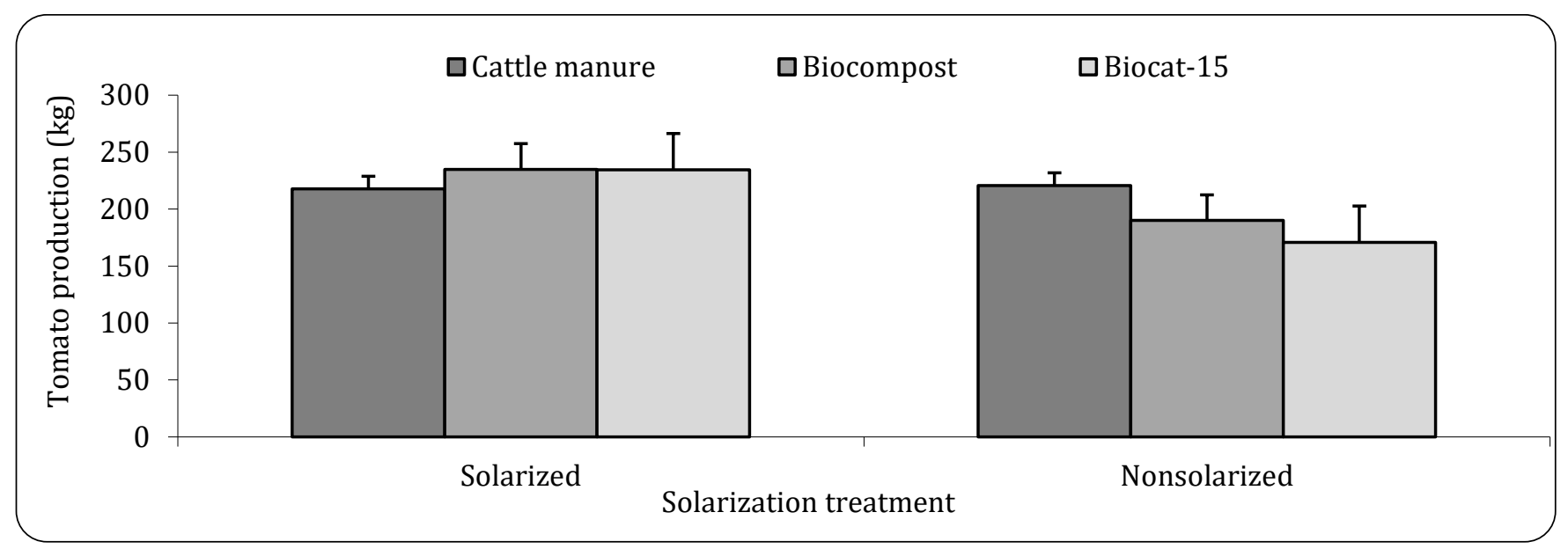


Figure 4: Tomato cv. Sahel production (kg) noted 190 days post-planting on depending on solarization treatment (solarized or non-solarized) and tested organic amendments. For each individual treatment, data presented are means for 280 plants. LSD (Solarization treatments $\mathrm{x}$ Organic amendments) $=14.75 \mathrm{~kg}$ at $P \leq 0.05$. 


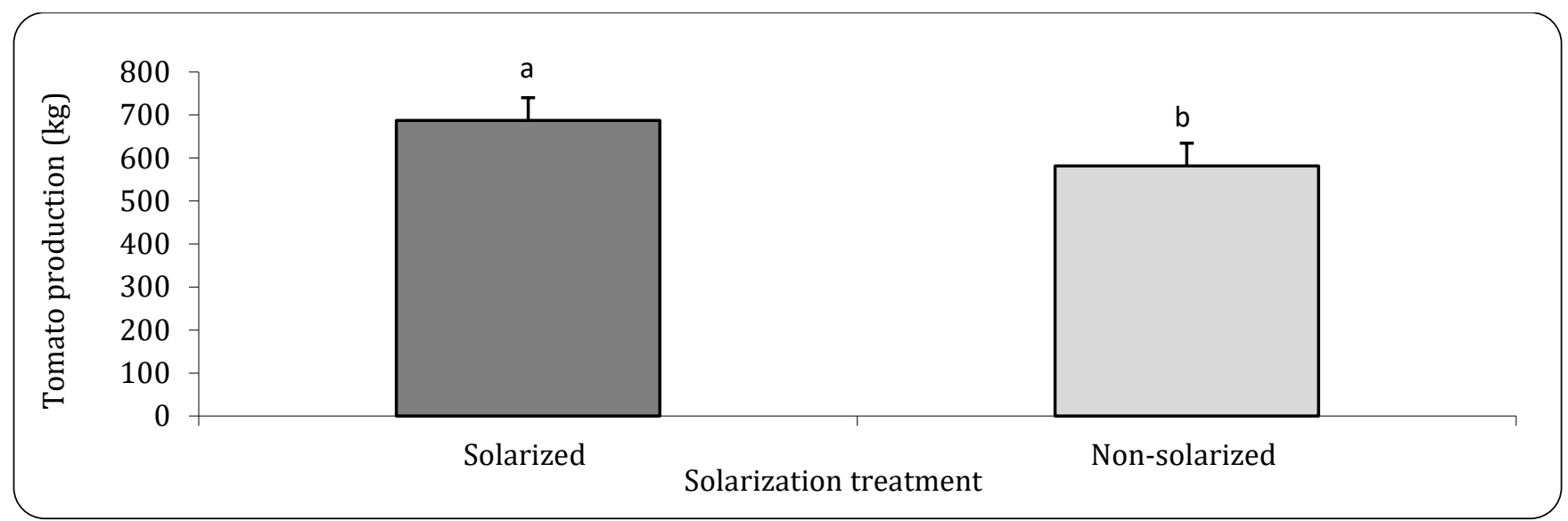

Figure 5: Tomato cv. Sahel production $(\mathrm{kg})$ noted 190 days post-planting in solarized and non-solarized greenhouses. Bars sharing the same letter are not significantly different, according to Duncan's Multiple Range test $(P \leq 0.05)$. For each solarization treatment, data presented are means for 280 plants.

\section{DISCUSSION}

Under suitable climatic conditions, soil solarization which is a non-chemical method of soil disinfestation can effectively suppress a wide range of soilborne pests, including fungi, bacteria, weeds, nematodes and insects, either directly, through physicothermal action, or indirectly, by stimulating antagonists and/or weakening the pathogen's resting structures present in the soil (Gilardi et al., 2014).

Results of our study further showed that, under natural greenhouse conditions, soil solarization was an effective soil disinfestation approach for suppressing soilborne diseases associated to tomato. In fact, a single application of soil solarization for 60 days had significantly reduced the severity of vascular wilt diseases as expressed by the lowered vascular discolouration extent, on randomly collected as well as on symptomatic plants as compared to the non-solarized soil. These diseases, as determined and confirmed through the performed fungal isolations, were mainly attributed to Fusarium oxysporum, F. solani, R. solani, and $C$. coccodes. Their isolation frequency has decreased following soil solarization. Our results are consistent with several previous reports stating the efficacy of soil solarization in reducing Fusarium Crown and Root Rot (due to F. oxysporum f. sp. radicis-lycopersici) (Gamliel et al., 2009) and Southern blight (caused by Sclerotium rolfsii) on tomato (Stevens et al., 2003), Charcoal rot (incited by Macrophomina phaseolina) of cowpea (Ndiaye et al., 2007), and Fusarium wilts of carnation (Melero-Vara et al., 2011), cucumber (Yao et al., 2016), and strawberry (Abada et al., 2014).
In the current investigation, the recorded decrease in wilt severity on tomato plants may be the combined effects of soil solarization and organic amendments. In fact, cattle manure is the most used animal manure by tomato growers in the study region. It is interesting to note that, in this experiment, tomato plants grown in solarized and cattle manure-amended plots did not show any fungal vascular proliferation. In fact, it has been stated that poultry and cattle manures, which are widely available in commercial quantities, seem to be an appropriate material to be used in combination with soil solarization (Mihajlovic et al., 2017). In the same sense, (Gilardi et al., 2014) mentioned that soil solarization combined with organic amendments displays great potential for controlling soilborne pathogens and is considered one of the most effective methods because it is ecologically friendly and with low costs. Previous results have also shown that the association of soil solarization with organic amendments is able to suppress the populations of various plant pathogens (Blok et al., 2000; Klein et al., 2011; Melero-Vara et al., 2011; Gilardi et al., 2014) as well as some formae speciales of $F$. oxysporum, F. solani and Fusarium equiseti as demonstrated in sweet pepper (Martínez et al., 2010).

However, the disease-suppressive potential of organic amendments tested in the present study against wilt severity is not constant and seems to be dependent on nature (randomly collected or symptomatic) of sampled plants. In fact, it has been suggested that the effectiveness of organic amendments, in suppressing soilborne plant diseases, depends greatly on their 
original composition, released amounts, and application method (McSorley, 2011; Simmons et al., 2016). Likewise, combining solarization with appropriate organic material activates a chain reaction of chemical and microbial degradation, generating antimicrobial compounds (Klein et al., 2007; Gamliel et al., 2009). Thus, it is possible that the reduced added efficacy of organic amendments tested in the current investigation could be due to the method of their application. In fact, in almost all studies describing the effect of organic amendment supply with solarization, the organic matter was incorporated into the soil before solarization, thus resulting in an additional rise in temperature which may be a supplementary factor leading to more efficient control of target pathogenic organisms. For example, Gamliel and Stapleton (1997) mentioned that the temperature of solarized soil amended with compost increased by $2-3{ }^{\circ} \mathrm{C}$ compared with the temperature rise recorded in solarized but non-amended soil. Furthermore, because of the long elapse of time between solarization, organic amendments application and planting tomato, it is possible that the lowered efficacy of soilborne diseases management could be the result of possible rapid soil recontamination. In addition, it is possible that in the case of highly infested soils, animal manure with high-nitrogen-containing organic materials should be applied, such as chicken manure. In fact, during their decomposition, the formed nitrogen ammonia is known to be highly toxic to several plant pathogens (Gamliel and Stapleton, 1997).

Results from the current experiment also demonstrated that, under natural greenhouse conditions, soil solarization applied singly or in combination with tested organic amendments had improved tomato production. In fact, soil solarization has the capacity to enhance the physical and chemical properties of the soil, improve plant growth and increase the yield of subsequent crops (Davis, 1991) probably through the release of nutrients induced by high temperature (Katan, 1981; Stapleton and DeVay, 1984; Chellemi et al., 1997). Also, according to Gamliel and Stapleton (1997), the combination of solarization and organic amendments often results in an increased crop yields. In the same sense, Mauromicale et al. (2010) mentioned that under the Mediterranean conditions, organic supplementation before soil solarization has been proven to be an excellent means of improving soil chemical properties and, consequently, plant growth and fruit yield of greenhouse-grown tomatoes.

\section{CONCLUSIONS}

Results from the current experiment showed that, under natural greenhouse conditions, a single application of solarization combined with organic amendment not only reduced vascular wilt severity but also significantly enhanced tomato production. However, additional trials are required to evaluate the effectiveness of two- or multi-year application of soil solarization. The combination of solarization with other soil amendments, especially those with high nitrogen/carbon ratios or with other control strategies such as the use of biocontrol agents, should also be explored. Further studies are needed to select which compositions, amounts, and application methods of organic amendments are the most effective when combined with soil solarization for the management of soilborne tomato diseases.

\section{ACKNOWLEDGEMENTS}

This work was carried out during a Collaborative Project Tunisia-Egypt Funded jointly by the Ministry of Scientific Research in Egypt (grand no.4/10/4) and the Ministry of Higher Education and Scientific Research of Tunisia.

\section{REFERENCES}

Abada, K. A., F. M. Abd-El-Latif and H. A. M. El-Dakar. 2014. Effect of combination among bioagents, compost and soil solarization on management of strawberry fusarium wilt. American Journal of Life Sciences, 2: 39-46.

Aydi Ben Abdallah, R., H. Jabnoun-Khiareddine, A. Nefzi, F. Ayed and M. Daami-Remadi. 2019. Field suppression of Fusarium wilt and microbial population Shifts in tomato rhizosphere following soil treatment with two selected endophytic bacteria. Eurasian Journal of Soil Sciences, 8: 208-20.

Blok, W. J., J. G. Lamers, A. J. Termorshuizen and G. J. Bollen. 2000. Control of soilborne plant pathogens by incorporating fresh organic amendments followed by tarping. Phytopathology, 90: 253-59.

Bonanomi, G., V. Antignani, C. Pane and F. Scala. 2007. Suppression of soilborne fungal diseases with organic amendments. Journal of Plant Pathology, 89: 311-24.

Chellemi, D. O., S. M. Olson, D. J. Mitchell, I. Secker and R. McSorley. 1997. Adaptation of Soil Solarization to the Integrated Management of Soilborne Pests of Tomato Under Humid Conditions. 
Phytopathology®, 87: 250-58.

Davis, J. R. 1991. Pathogen and disease control and increases in crop yield and quality: Short-and long-term effects and integrated control. In: J Katan and J E DeVay (eds.), Soil solarization. CRC Press: Boca Raton, FL, USA.

El-Mohamedy, R. S. R., H. Jabnoun-Khiareddine and M. Daami-Remadi. 2014. Control of root rot diseases of tomato plants caused by Fusarium solani, Rhizoctonia solani and Sclerotium rolfsii by using different chemical plant resistance inducers. Tunisian Journal of Plant Protection, 9: 45-55.

Freeman, S. and J. Katan. 1988. Weakening effect on propagules of Fusarium by sublethal heating. Phytopathology, 78: 1656-61.

Gamliel, A., M. Siti, A. Arbel and J. Katan. 2009. Soil solarization as a component of the integrated management of Fusarium crown and root rot in tomato. Acta Horticulturae: 321-26.

Gamliel, A. and J. J. Stapleton. 1993. Effect of chicken compost or ammonium phosphate and solarization on pathogen control, rhizosphere microorganisms, and lettuce growth. Plant disease, 77: 886-91.

Gamliel, A. and J. J. Stapleton. 1997. Improvement of soil solarization with volatile compounds generated from organic amendments. Phytoparasitica, 25: S31-S38.

Gilardi, G., S. Demarchi, M. L. Gullino and A. Garibaldi. 2014. Effect of simulated soil solarization and organic amendments on Fusarium wilt of rocket and basil under controlled conditions. Journal of Phytopathology, 162: 557-66.

Hibar, K., M. Daami-Remadi and M. El-Mahjoub. 2007. Induction of resistance in tomato plants against Fusarium oysporum f. sp. radicis-lycopersici by Trichoderma spp. Tunisian Journal of Plant Protection, 2: 47-58.

Hibar, K., M. Daami-Remadi, H. Jabnoun-Khiareddine and M. E. Mahjoub. 2006a. Control of fusarium crown and root rot of tomato, caused by Fusarium oxysporum f. sp. radicis-lycopersici, by grafting on to resistant rootstocks. Plant Pathology Journal, 5: 161-65.

Hibar, K., M. Daami-Remadi, H. Jabnoun-Khiareddine, I. E. A. Znaidi and M. El Mahjoub. 2006b. Effet des extraits de compost sur la croissance mycélienne et l'agressivité du Fusarium oxysporum f. sp. radicis-lycopersici. Biotechnologie, Agronomie, Société et Environnement, 10: 101-08.

Hibar, K., M. Daami-Remadi, H. Khiareddine and M. El Mahjoub. 2005. Effet inhibiteur in vitro et in vivo $\mathrm{du}$ Trichoderma harzianum sur Fusarium oxysporum f. sp. radicis-lycopersici. Biotechnologie, Agronomie, Société et Environnement, 9: 163-71.

Jabnoun-Khiareddine, H., R. Aydi-Ben-Abdallah, A. Nefzi, F. Ayed and M. Daami-Remadi. 2019. Grafting tomato cultivars for soilborne disease suppression and plant growth and yield improvement. Journal of Plant Pathology and Microbiology, 10: 473.

Jabnoun-Khiareddine, H., M. Daami-Remadi, F. Ayed and M. El Mahjoub. 2009a. Biocontrol of tomato Verticillium wilt by using indigenous Gliocladium spp. and Penicillium sp. isolates. Dynamic Soil, Dynamic Plant, 3: 70-79.

Jabnoun-Khiareddine, H., M. Daami-Remadi, F. Ayed and M. El Mahjoub. 2009b. Biological control of tomato Verticillium wilt by using indigenous Trichoderma spp. African Journal of Plant Science and Biotechnology, 3: 26-36.

Jabnoun-Khiareddine, H., R. S. R. El-Mohamedy, F. AbdelKareem, R. Aydi-Ben-Abdallah, M. GueddesChahed and M. Daami-Remadi. 2015. Variation in chitosan and salicylic acid efficacy towards soilborne and air-borne fungi and their suppressive effect of tomato wilt severity. Journal of Plant Pathology and Microbiology, 6: 325.

Katan, J. 1981. Solar heating (Solarization) of soil for control of soilborne pests. Annual review of phytopathology, 19: 211-36.

Katan, J. and J. E. Devay. 1991. Soil Solarization. CRC Press: Boca Raton, USA.

Keinath, A. P. 1996. Soil amendment with cabbage residue and crop rotation to reduce gummy stem blight and increase growth and yield of watermelon. Plant disease, 80: 564-70.

Kerkeni, A., M. Daami-Remadi, N. Tarchoun and M. Ben Khedher. 2007. In vitro and in vivo suppression of Fusaruim oxysporum f. sp. radicis-lycopersici the causal agent of fusarium crown and root rot of tomato by some compost fungi. International Journal of Agricultural Research, 2: 1022-29.

Klein, E., J. Katan, M. Austerweil and A. Gamliel. 2007. Controlled laboratory system to study soil solarization and organic amendment effects on plant pathogens. Phytopathology, 97: 1476-83. 
Klein, E., J. Katan and A. Gamliel. 2011. Soil suppressiveness to fusarium disease following organic amendments and solarization. Plant disease, 95: 1116-23.

Martínez, M. A., M. C. Martínez, P. Bielza, J. Tello and A. Lacasa. 2010. Effect of biofumigation with manure amendments and repeated biosolarization on Fusarium densities in pepper crops. Journal of Industrial Microbiology and Biotechnology, 38: 3-11.

Mauromicale, G., A. L. Monaco and A. M. G. Longo. 2010. Improved efficiency of soil solarization for growth and yield of greenhouse tomatoes. Agronomy for Sustainable Development, 30: 753-61.

McSorley, R. 2011. Overview of organic amendments for management of plant-parasitic nematodes, with case studies from Florida. Journal of Nematology, 43: 69-81.

Melero-Vara, J. M., C. J. López-Herrera, A. M. PradosLigero, M. D. Vela-Delgado, J. A. Navas-Becerra and M. J. Basallote-Ureba. 2011. Effects of soil amendment with poultry manure on carnation fusarium wilt in greenhouses in southwest Spain. Crop Protection, 30: 970-76.

Mihajlovic, M., E. Rekanovic, J. Hrustic, M. Grahovac and B. Tanovic. 2017. Methods for management of soilborne plant pathogens. Pesticidi i fitomedicina, 32: 9-24.

Ndiaye, M., A. J. Termorshuizen and A. H. C. Van Bruggen. 2007. Combined effects of solarization and organic amendment on charcoal rot caused by Macrophomina phaseolina in the sahel. Phytoparasitica, 35: 392-400.

Nefzi, A., R. A. B. Abdallah, H. Jabnoun-Khiareddine, N. Ammar and M. Daami-Remadi. 2019. Ability of endophytic fungi associated with Withania somnifera L. to control fusarium crown and root rot and to promote growth in tomato. Brazilian Journal of Microbiology, 50: 481-94.

Nefzi, A., H. Jabnoun-Khiareddine, R. Aydi Ben Abdallah, N. Ammar, S. Medimagh-Saïdana, R. Haouala and M. Daami-Remadi. 2017. Suppressing fusarium crown and root rot infections and enhancing the growth of tomato plants by Lycium arabicum Schweinf. Ex Boiss. extracts. South African Journal of Botany, 113: 288-99.

Simmons, C. W., B. Higgins, S. Staley, L. D. Joh, B. A. Simmons, S. W. Singer, J. J. Stapleton and J. S. VanderGheynst. 2016. The role of organic matter amendment level on soil heating, organic acid accumulation, and development of bacterial communities in solarized soil. Applied Soil Ecology, 106: 37-46.

Stapleton, J. J. and J. E. DeVay. 1984. Thermal components of soil solarization as related to changes in soil and root microflora and increased plant growth response. Phytopathology, 74: 255-59.

Stevens, C., V. A. Khan, R. Rodriguez-Kabana, L. D. Ploper, P. A. Backman, D. J. Collins, J. E. Brown, M. A. Wilson and E. C. K. Igwegbe. 2003. Integration of soil solarization with chemical, biological and cultural control for the management of soilborne diseases of vegetables. Plant and Soil, 253: 493-506.

Syngenta. 2015. Tomato Sahel: Crops and Products. https://www.syngenta.co.za/sites/g/files/zhg436 /f/sahel.pdf?token=1531405417.

Yao, Y., Z. Xue, C. Hong, F. Zhu, X. Chen, W. Wang, Z. Cai, N. Huang and X. Yang. 2016. Efficiency of different solarization-based ecological soil treatments on the control of fusarium wilt and their impacts on the soil microbial community. Applied Soil Ecology, 108: 341-51.

\section{CONFLICT OF INTEREST}

All authors declare that they have no conflict of interest.

\section{AUTHORS CONTRIBUTIONS}

All authors participated in the design of the study, data collection and data analysis. They read and approved the final manuscript.

Publisher's note: EScience Press remains neutral with regard to jurisdictional claims in published maps and institutional affiliations.

Open Access This article is licensed under a Creative Commons Attribution 4.0 International License. To view a copy of this license, visit http://creativecommons.org/licenses/by/4.0/. 